\title{
INFLUENCE OF PROJECT METHODS ON LEARNERS' LEARNING OUTCOMES IN DRAMA COURSES IN PANDEMIC ERA
}

\author{
Tamaela Ida Costansa ${ }^{1}$, Marshalo Rovianto Kakerissa ${ }^{2}$, Windy Putri Latuheru ${ }^{3}$ \\ Pattimura University, German Language Education Study Program ${ }^{123}$ \\ Email: idatamaela@yahoo.com
}

\begin{abstract}
The purpose of this study is to describe the effectiveness of project methods in pandemic times in drama courses in the German Language Education Study Program. The respondents in the study were fifth-semester students. The project phase in this research consists of 7 phases, namely: 1) Preparation phase (Vorbereitungsphase); 2) Early phasel (Einstiegsphase); 3) Planning phase (Planungsphase); 4) Implementation and realization phases (Ausführungsphase). 5) Evaluation and control phase (Auswertungsphase); 6) Final Results Phase (Ergebnis präsentation), and 7. Closing phase (Abschluss). According to Reich, K: Data collection techniques using qualitative descriptive methods. The end result of the project is to create a picture book about Maluku folklore (Märchen). Maluku folklore book is made following the script of the drama from Esser Rolf, namely: The beginning, conflict situation, climax, redah, and end. The final results of the project showed 4 respondents got a score of 70, 3 respondents got a score of : 80, 7 respondents got a score of 90 , and 3 respondents got a score of 100. Based on the assessment score of the final results of learning, it can be concluded that the project method has a positive influence on the learning outcomes of Drama courses.
\end{abstract}

Keywords: project methods, pandemic era, Drama courses, learning outcomes

\section{Introduction}

Since the pandemic hit the globe, all work has been done at home, including the learning process. One of the courses that have been taking place at home is drama courses, where the staging is made set in tourist attractions. With the stage outside the classroom makes learners confident and have no fear to express freely.

Drama courses are taught on german language education study programs, with the aim of being able to improve learners' speaking skills in German. Therefore, to overcome these circumstances, creativity and innovation from a teacher is needed, in order to create a pleasant learning atmosphere, which is the right method that can be used during a pandemic or work from home by emphasizing the responsibility of learners. The method chosen in this research is the Project method with the aim that learners not only acquire knowledge, but also the ability to work in teams and be able to solve problems together, as well as gain experience in project work. Furthermore, regular meetings with teachers are also conducted so that teachers can follow the development of the ongoing project process. At the end of the project was held a presentation of the work of learners in the form of picture books with the theme of Maluku folklore in two languages, namely German - Indonesian. According by fuer Lehre und Lernen Universität Stuttgart 
“Das Ziel von Projektarbeiten ist es, dass Studierende neben fachlichen Kompetenzen auchTeamfähigkeit und Problem löse kompetenz erwerben sowie Erfahrungen in der Projektarbeit sammeln können. Sie arbeiten gemeinsam ein Semester (oderlänger) lang an einemThema selbst gewählten oder vorgegebenem Thema. Regelmäßige Besprechungen mit dem Betreuer unterstützen das Projektteam. Am Ende steht die Präsentation der Ergebnisse vor einem Publikum, einem Abschluss bericht oder in Form einer gemeinsamen"

It is said that work in the project is a collaborative activity in a team that can overcome problems together. Furthermore, he said that the project can last for one semester on a specific topic. That is, the project is adjusted to the allocation of time that has been designed for one semester at home. The results achieved by learners in this study are picture folklore books. (Bilderbuch).

„Ein Projekt im Rahmen schulischen Unterrichts ist ein Vorhaben, das von Lehrern und Schülern gemeinsam getragen und verantwortet wird und das sich auszeichnet durch eine begrenzte Bezogenheit auf die Gesellschaft.

That is, a project in teaching is the responsibility of teachers and learners. This method utilizes online networks, and can make creative learners use the facilities around the house or do all learning activities through online systems. Using a full online method like this, the learning system delivered will continue and all learners remain in their homes safe.

\section{Research Method}

The research method used is descriptive qualitative, which describes the project method in drama learning. The project method in this research is not only obtained from the end result of learning, but also the process. (Uno, 2012: 22). The final result of drama learning is a product of a picture book themed on Maluku folklore. Learners can display the final product of a project in the form of a presentation to assess their ability to communicate the findings of their findings in a report (literary work) This activity can be used to assess the ability of learners individually or group.

The product assessment in this study was assessed by phase by Reich in Unterrichtsmethode, which can be seen in the scheme below. : 


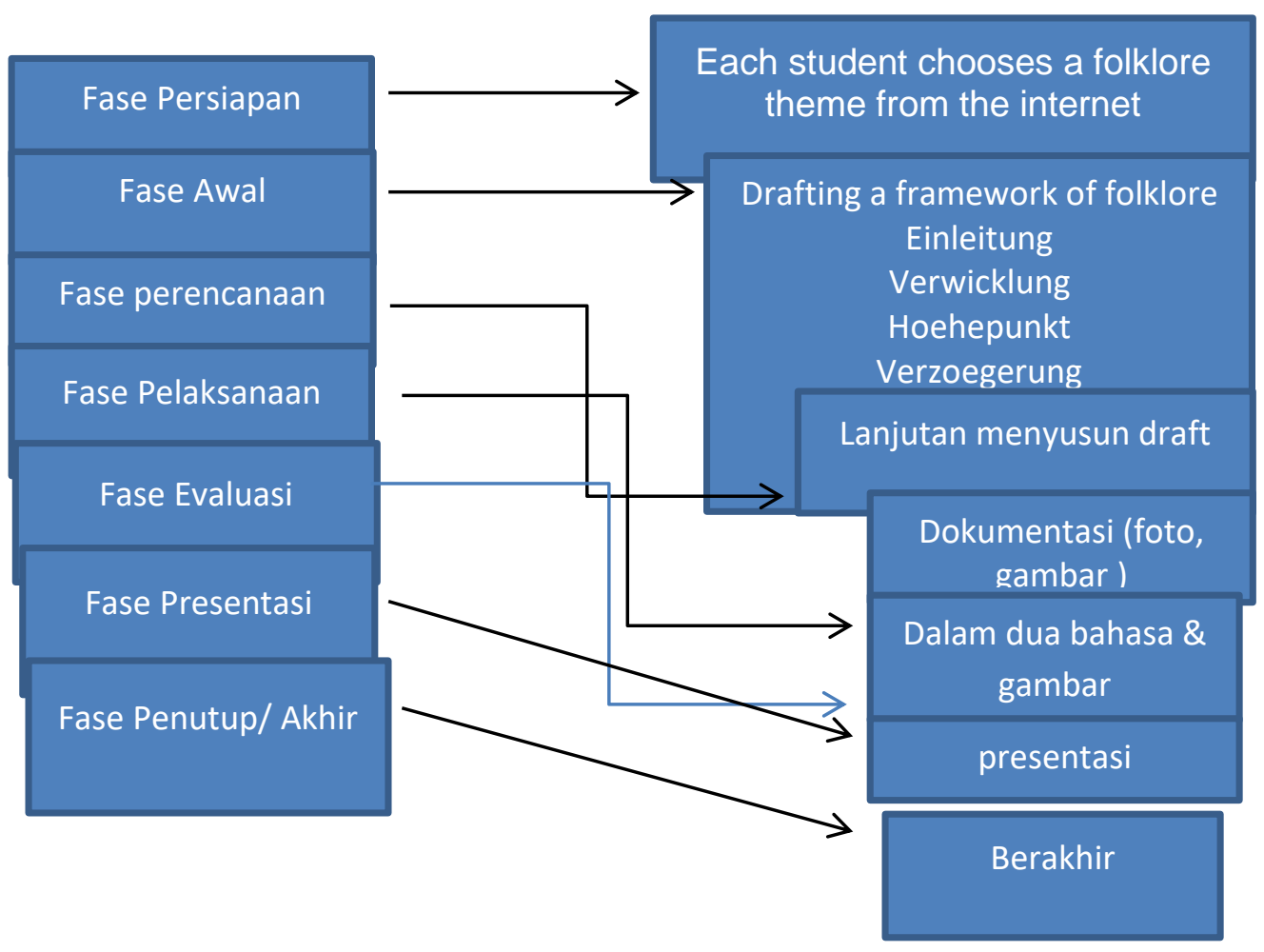

The subjects of this study are learners who follow drama courses in the FKIP Unpatti German language education study program which numbers 17 learners.

\section{Results and Discussions}

Learning in networking or distance is not the same as face-to-face learning, both in terms of time and methods used. So that the implementation of learning from home, becomes the subject of teacher consideration of the learning burden of learners. This is intended so that the learning situation becomes fun for learners even though learning distancely. Therefore, drama learning projects are carried out for a maximum of one hour for one meeting virtually (through zoom meetings). There, the students are given materials and instructions on what to do. Then the learner makes a task and sent in google classroom / or email that will be checked and will be discussed the following week by the teacher.

Here is the implementation of the project by Reich $\mathrm{K}$. which can be seen in the table below.

\begin{tabular}{|l|l|l|l|l|l|}
\hline $\begin{array}{l}\text { Perte } \\
\text { muan } \\
\text { Zoom }\end{array}$ & Materi zoom & $\begin{array}{l}\text { Tugas Kegiatan } \\
\text { Projektarbeit }\end{array}$ & $\begin{array}{l}\text { Durasi wktu } \\
\text { Projektarbeit }\end{array}$ & WhatsApp & $\begin{array}{l}\text { Google } \\
\text { classroom }\end{array}$ \\
\hline
\end{tabular}




\begin{tabular}{|c|c|c|c|c|c|}
\hline 1 & $\begin{array}{l}\text { Fase persiapan } \\
\text { (Vorbereitung) } \\
\text { Konsep drama } \\
\text { \& cerita rakyat }\end{array}$ & $\begin{array}{l}\text { Menemukan } \\
\text { informasi atau } \\
\text { data tentang cerita } \\
\text { rakyat Maluku } \\
\text { melalui internet } \\
\text { atau } \\
\text { sumber lainnya } \\
\text { (tokoh } \\
\text { masyarakat) } \\
\text { hanya internet, tdk } \\
\text { ada sumber lain/ } \\
\text { tokoh masy }\end{array}$ & $\begin{array}{l}7 \text { hari (satu } \\
\text { minggu) }\end{array}$ & 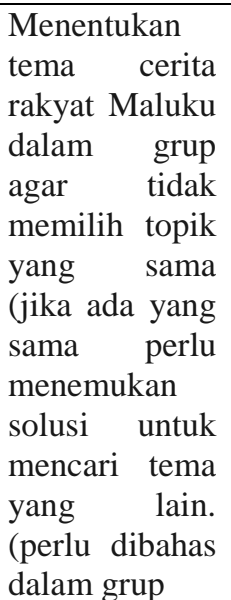 & \\
\hline 2 & $\begin{array}{l}\text { Fase awal } \\
\text { (Einstieg) } \\
\text { Langkah- } \\
\text { langkah } \\
\text { menyusun } \\
\text { sinopsis cerita } \\
\text { rakyat } \\
\text { (berdasarkan } \\
\text { (Rolf Esser) }\end{array}$ & $\begin{array}{l}\text { Menyusun } \\
\text { kerangka cerita } \\
\text { rakyat sesuai tema } \\
\text { masing-masing } \\
\text { yang sudah } \\
\text { ditentukan oleh } \\
\text { masing-masing } \\
\text { mahasiswa } \\
\text { Yang dibahas } \\
\text { adalah: Tentang } \\
\text { thema apa ? } \\
\text { Masalah dan } \\
\text { solusi dari cerita } \\
\text { tsb, bagaimana } \\
\text { ceritanya berakhir } \\
?\end{array}$ & $\begin{array}{l}14 \text { hari } \\
(2 \text { minggu) }\end{array}$ & $\begin{array}{l}\text { Absen } \\
\text { dilakukan } \\
\text { setiap minggu } \\
\text { dengan } \\
\text { perkembangan }\end{array}$ & $\begin{array}{l}\text { Menyerahka } \\
\mathrm{n} \quad \text { Draft } \\
\text { kerangka } \\
\text { tulisan } \\
\text { Koreksi } \\
\text { untuk } \\
\text { perbaikan }\end{array}$ \\
\hline 4 & $\begin{array}{l}\text { Fase } \\
\text { Perencanaan } \\
\text { (Plannung) } \\
\text { (draft) } \\
\text { melengkapi } \\
\text { cerita rakyat }\end{array}$ & $\begin{array}{lr}\text { Menyusun } & \text { draft } \\
\text { cerita rakyat } \\
\text { mengikuti tahapan } \\
\text { alur cerita Rolf } \\
\text { Esser }\end{array}$ & $\begin{array}{l}14 \text { hari } \\
(2 \text { minggu })\end{array}$ & Absen & $\begin{array}{l}\text { Menyerahka } \\
\mathrm{n} \quad \text { tulisan } \\
\text { cerita rakyat } \\
\text { (melengkapi } \\
\text { ) }\end{array}$ \\
\hline 6 & $\begin{array}{l}\text { Fase } \\
\text { pelaksanaan } \\
\text { (Realisation) }\end{array}$ & $\begin{array}{l}\text { Dokumentasi } \\
\text { Proses dan hasil } \\
\text { (gambar /foto) } \\
\text { dibuat dlm } 2 \text { bhs } \\
\text { (Jerman-Indo) }\end{array}$ & $\begin{array}{l}21 \text { hari } \\
\text { (3 minggu) }\end{array}$ & Absen & $\begin{array}{l}\text { Menyerahka } \\
\mathrm{n} \quad \text { tulisan } \\
\text { cerita rakyat } \\
\text { dengan } \\
\text { gambar / } \\
\text { foto }\end{array}$ \\
\hline 9 & $\begin{array}{l}\text { Auswertung } \\
\text { (Evaluation) }\end{array}$ & $\begin{array}{lr}\text { Menyusun } & \text { dalam } \\
\text { dua } & \text { bahasa } \\
\text { (Jerman } & -\end{array}$ & $\begin{array}{l}21 \text { hari } \\
\text { (3 minggu) }\end{array}$ & Absen & \begin{tabular}{lr}
\multicolumn{2}{c}{ Menyerahka } \\
$\mathrm{n} \quad$ tulisan \\
cerita & rakyat
\end{tabular} \\
\hline
\end{tabular}




\begin{tabular}{|l|l|l|l|l|l|}
\hline & & $\begin{array}{l}\text { Indonesia/ bhs } \\
\text { ambon) }\end{array}$ & & & $\begin{array}{l}\text { dengan } \\
\text { gambar / } \\
\text { foto dan } \\
\text { dibuat } \\
\text { Dalam dua } \\
\text { bahasa } \\
\text { Jerman } \\
\text { Indonesia) }\end{array}$ \\
\hline 12 & $\begin{array}{l}\text { Presentasi } \\
\text { (powerpoint) }\end{array}$ & & $\begin{array}{l}\text { Menyerahka } \\
\text { n PPT }\end{array}$ \\
\hline 14 & $\begin{array}{l}\text { Buku } \\
\text { (Bilderbuch) }\end{array}$ & & $\begin{array}{l}14 \text { hari } \\
(2 \text { minggu })\end{array}$ & Absen & $\begin{array}{l}\text { Menyerahka } \\
\text { ne email }\end{array}$ \\
\hline 16 & $\begin{array}{l}\text { Abschluss } \\
\text { Penilaian } \\
\text { Produk }\end{array}$ & & $\begin{array}{l}14 \text { hari } \\
(2 \text { minggu })\end{array}$ & Absen & $\begin{array}{l}\text { Penilaian } \\
\text { Akhir }\end{array}$ \\
\hline
\end{tabular}

\section{Assessment Aspects}

The assessment aspect used is to create a picture story themed maluku folklore based on the steps of Rolf Esser. The given score is to give greater weight to the aspects that take precedence (Moch Abduh, 2019: 9) Here are the steps of aspects assessed by the level of the score given:

\begin{tabular}{|c|c|c|}
\hline $\begin{array}{c}\text { No } \\
\text { urut }\end{array}$ & Aspek yang dinilai & Tingkat Skor yang dicapai \\
\hline 1 & $\begin{array}{l}\text { Einleitung, menjelaskan tempat, waktu dan } \\
\text { tokoh yang berperan dalam cerita rakyat } \\
\text { yang disusun dan peristiwa apa yang terjadi }\end{array}$ & $0-10$ \\
\hline 2 & $\begin{array}{l}\text { Verwicklung, menjelaskan tentang situasi } \\
\text { konflik yang terjadi }\end{array}$ & $0-10$ \\
\hline 3 & $\begin{array}{l}\text { Höhepunkt der Handlung, menerangkan } \\
\text { tentang puncak peristiwa yang terjadi/ } \\
\text { klimaks; }\end{array}$ & $0-20$ \\
\hline 4 & $\begin{array}{l}\text { Verzögerung, menjelaskan situasi konflik } \\
\text { yang terjadi apakah semakin meningkat } \\
\text { atau mulai mereda }\end{array}$ & $0-20$ \\
\hline 5 & $\begin{array}{l}\text { Lösung, situasi berakhirnya konflik, baik } \\
\text { atau buruk. }\end{array}$ & $0-40$ \\
\hline & TOTAL & 100 \\
\hline
\end{tabular}

Based on the score level specified in the table above, the results of the assessment of Folklore products in drama courses from 17 learners are as follows:

\begin{tabular}{|c|c|c|c|c|c|c|c|}
\hline $\begin{array}{c}\text { No } \\
\text { responden }\end{array}$ & Einleitung & Verwicklung & $\begin{array}{c}\text { Hoehe- } \\
\text { punkt }\end{array}$ & $\begin{array}{c}\text { Verzoeger- } \\
\text { ung }\end{array}$ & Loesung & total & $\begin{array}{c}\text { Nilai } \\
\text { akhir }\end{array}$ \\
\hline 1 & 10 & 0 & 20 & 20 & 40 & 90 & 90 \\
\hline 2 & 0 & 10 & 20 & 0 & 40 & 70 & 70 \\
\hline 3 & 10 & 10 & 20 & 20 & 40 & 100 & 100 \\
\hline
\end{tabular}




\begin{tabular}{|c|c|c|c|c|c|c|c|}
\hline 4 & 0 & 10 & 20 & 0 & 40 & 70 & 70 \\
\hline 5 & 10 & 0 & 20 & 20 & 40 & 90 & 90 \\
\hline 6 & 10 & 10 & 20 & 20 & 40 & 100 & 100 \\
\hline 7 & 10 & 0 & 20 & 20 & 40 & 90 & 90 \\
\hline 8 & 0 & 0 & 20 & 20 & 40 & 80 & 80 \\
\hline 9 & 10 & 10 & 20 & 20 & 40 & 100 & 100 \\
\hline 10 & 10 & 10 & 20 & 0 & 40 & 80 & 80 \\
\hline 11 & 0 & 10 & 20 & 20 & 40 & 90 & 90 \\
\hline 12 & 10 & 0 & 20 & 20 & 40 & 90 & 90 \\
\hline 13 & 10 & 0 & 20 & 20 & 40 & 90 & 90 \\
\hline 14 & 0 & 0 & 20 & 20 & 40 & 80 & 80 \\
\hline 15 & 10 & 0 & 0 & 20 & 40 & 70 & 70 \\
\hline 16 & 10 & 0 & 20 & 20 & 40 & 90 & 90 \\
\hline 17 & 10 & 0 & 0 & 20 & 40 & 70 & 70 \\
\hline
\end{tabular}

The final results of the above assessment showed that 4 respondents obtained a total score of 70,3 respondents obtained a score of 80,7 respondents obtained a score of 90, and 3 respondents obtained a score of 100. Based on the final results assessment score of drama learning with project methods, it can be concluded that the project method is a good method to apply in learning..

\section{Products produced}

The products produced in this project are 17 picture story books (Bildbuecher) in two languages, namely German and Indonesian produced over a semester with different themes. The story is themed on local folklore in Maluku. Stories are arranged chronologically according to the time of occurrence of events and follow the inner structure of the drama. ( Esser 2010 : 126) namely: a) Einleitung, describes the place, time and figures that play a role in the folklore that is compiled and what events occur; b) Verwicklung, Explaining about the conflict situation that occurred; c) Höhepunkt der Handlung, Explaining the peak of the event that occurred / climax; d) Verzögerung, explain the situation of the conflict that occurs whether it increases or subsides; and e) Lösung, The end of the conflict, good or bad. With this project method, at the end of learning students are trained to be able to display what they have done. In this case, students learn to innovate, think critically, develop their social competence through cooperation with other friends, so that students feel comfortable and free in learning with supervision from teachers..

\section{Conclusion}

Based on the final results of this study, it can be concluded that one of the learning methods that can maximize learning at the time of this pandemic is the project method. With this project method learners can continue to do their duties with supervision by the teacher according to the schedule made. In this case, the provision of material is still done at the appointed time. With the google classroom application, the timeliness of task delivery can be controlled properly. Interaction between 
learners and teachers can take place effectively. The tasks given can also encourage learners to be more creative and innovative.

\section{References}

Esser R. 2007. Das grosse Arbeitsbuch Literaturunterricht. Lyrik, Epik, Dramatik. Muelheim an der Ruhr, Verlag an der Ruhr

Nurgiyantoro Burhan, 2011 Penilaian Otentik Dalam Pembelajaran Bahasa, Yogyakarta, Gadjah Mada University Press.

Uno Hamzah \& Koni S. 2012. Assessment Pembelajaran. Jakarta. PT Bumi Aksara

Internet Source

Moch Abduh, 2019 Panduan Penilaian Kinerja (Performance Assessment)

Pusat penilaian Pendidikan Badan Penelitian dan pengembangan Kementerian Pendidikan dan Kebudayaan, Jakarta. Pusat Penilaian Pendidikan Panduan Penilaian Kinerja (Performance ..https:

//pusmenjar.kemdikbud.go.id > file-9

Reich K. Projektarbeit - Unterrichtsmethoden im konstruktiven und ..http://methodenpool.uni-koeln.de > projektmethode

Fuer Lehre und Lernen Universität Stuttgart. Das Ziel von Projektarbeiten https://ilias3.uni-stuttgart.de/goto.php?target=cat_1948111

Was ist Projektarbeit https://www.grin.com/document/71385 